\title{
THE PAROUSIA IN MODERN THEOLOGY: SOME QUESTIONS AND COMMENTS
}

\author{
By ANTHONY C. THISELTON
}

My aim is to provide a survey of approaches to the parousia in modern theology, and to formulate a number of questions and critical comments which these approaches suggest. In the main part of my paper I propose to describe and assess these modern approaches within their own proper theological and historical context. Then, towards the end, I shall try to set out my own approach to the subject, showing where we may draw fruitfully upon modern insights and where we must take warnings from modern misunderstandings.

One particular problem of procedure arises. Modern theology includes a wide variety of approaches to questions about eschatology, or about the future, which nevertheless give little or no consideration to the parousia. Should such approaches be examined in the present discussion? I suggest a compromise by beginning with a shorter discussion in which we shall glance very briefly at three approaches of this kind with little or no critical comment.

Firstly, process thought has much to say about the future. This movement entered theology some twelve years ago in North America, and calls to mind the names of D. D. Williams, John Cobb, Schubert Ogden, and Norman Pittenger. In 1964 Pittenger introduced it to this country in a lecture entitled "A Contemporary Trend in North American Theology."1 This

This paper was read at a meeting of the Tyndale Fellowship at Tyndale House, Cambridge, in July, 1975.

1 N. Pittenger, "A Contemporary Trend in North American Theology: the Significance of Process Thought" reprinted from the Expository Times 76 (1965) in God in Process S. C. M., London (1967) 96-109. This book also provides a useful introduction to the movement, including the chapter on man's destiny, pp. 86-95. (See also the book edited by E. H. Cousins, cited below.) 
movement looks back to the process-philosophy of A. N. Whitehead (1861-1949) and also to the philosophy of his pupil Charles Hartshorne. Its central idea is that reality is becoming rather than being, that it is dynamic rather than static. Taking his cue from emergent evolution and more especially from Einstein's theory of relativity, Whitehead saw the universe as something "alive". Ever on-the-move, it progressed as it changed, and it changed as it progressed. Process theologians argue that if God is the ground of this kind of universe, indeed if reality itself has this nature, God cannot merely be regarded as the timeless absolute of Platonism. Such a God is a mere abstraction of human thought. It is nearer to the Biblical notion of the living God who acts in history, it is argued, to see him as one who shares out his love actively in a dynamic and ongoing process.

Process theologians draw inferences from this for a view of the future. God is love, and the whole process is more than the individual. Hence Christian hope is centred not upon the individual himself, but upon the community and even the whole cosmos. In a startlingly imaginative vision of the future John Cobb tells how "each new experience would inherit from the past experiences of all" because there will be "a total openness of each to all the others". Thus each will enjoy "an inconceivable richness of values and meanings". 2

Even if this is speculation, it does provide one possible way of elucidating Paul's words about the eschatological character of love: "Love never ends, as for prophecy, it will pass away; as for tongues, they will cease ... When the perfect comes the imperfect will pass away" (1 Cor. 13.8-10).

A further implication of process thought may also be suggested. If God himself cannot be conceived of in static terms, neither can the End, of which he is still the ground. The end of history, it may be inferred, will not constitute the termination of all activity. It will not usher in an era of boredom in which nothing can happen. Process throught reminds us that God by his very nature is an ongoing God. In contrast to all that is static or stagnant, the future will open new horizons. Its reality and its substance will be fresh, creative, and vibrant.

It would be part of our criticism of process theology that it

2 J. B. Cobb Jr., "What is the Future? A Process Perspective" in E. H. Cousins (ed.- Hope and the Future of Man The Teilhard Centre and the Garnstone Press, London (1973) 13, 14. 
is difficult to say what place, if any, the parousia occupies in all this. Most process writers seldom if ever mention this subject, although they frequently concern themselves with the future. This is why we cannot strictly describe process theology as an approach to the parousia at all. However, as an account of the future in general it contains certain insights which are relevant, by implications to the Christian hope. It reminds us that the Biblical imagery of rest (Heb. 3.11, 18; 4.1-11; Rev. 14.13) should also be balanced by the other Biblical model of waking up to a new day (1 Cor. 15, 51, 52; Eph. 5.14; 1 Thess. 4.14). The parousia will not close the era of divine creativity, for God is the living God, and where there is life there is happening. God will yet work fresh wonders beyond our present imaginings. Further, process thought reminds us that Biblical eschatology is not merely centred on the individual and his particular destiny at death. This is not to deny that this point can be made simply on the basis of Biblical theology. J. A. T. Robinson, for example, makes the point strikingly in his introduction to In the End, God... ${ }^{3}$ :The parousia is not simply the moment when Christ confronts the individual; it is a cosmic event enacted on a cosmic scale and entails the gathering of all the elect. Process thought, however, adds a new depth to this perspective, with the result that firstly God and then the whole community occupy the centre of the eschatological stage, and not the individual and his moment of death.

The same kind of problem attaches to the work of Teilhard de Chardin. He is ready to speak about the future, but has little to say about the parousia. He considers that we cannot understand the full meaning of life without reference to man's future destiny. This destiny, which Teilhard describes as the Omega point of the total evolutionary process, constitutes a point of convergence and unification. It entails the bringing together into harmony of diverse races and cultures into a single wholeness in which God becomes all in all (cf. 1 Cor. 15.28). Although, as in process thought, this means the end of individualism, it nevertheless carries with it an enrichment and intensification of personhood.

Teilhard's perspective combines an acceptance of Paul's insight that "in Christ all things hold together" ( Col. 1.17;

3 J. A. T. Robinson, In the End, God ... Clarke, London (1950) 10-12. 
cf. Eph. 1.10) with the belief that reality is activated, as it were, from ahead; from the nature of its goal. At the same time, we must repeat the point which we made about process-thought, namely that the place of the parousia in all this is ambiguous. For the most part the subject is ignored, but occasionally it seems to be suggested that the parousia will occur only after man has already reached the Omega point. In either case, the event would remain extraneous to Teilhard's eschatological scheme. For it would not be the parousia that would fully establish the reign of Christ, but the immanent processes of God at work in the world. ${ }^{4}$

Paul Tillich provides a third example of a theology of the future in which the parousia plays virtually no part. All the imagery of eschatology, including presumably the parousia, is at most a symbol expressing the conviction that history has an end and a goal. At one point Tillich insists that none of this imagery stands for "things which will happen"; but it is only "the symbolic expression of the relation of the temporal to the eternal". From an existential viewpoint, it is not "a catastrophe in time and space", but "an expression of our standing in every moment in face of the eternal." 5 This outlook, as we shall see, has close affinities with that of Rudolf Bultmann.

Nevertheless Tillich does not seem to wish to empty this imagery of all ontological meaning. Just as behind the symbol of creation lies the objective fact of man's dependence on God, so behind the symbol of the eschaton lies the fact that man's creaturely yearnings will be fulfilled. We must not abandon the futurist dimension of eschatology, Tillich concedes, for we must look "ahead towards the end of history". 6 Tillich does in fact provide some content and substance to this hope of future fulfilment. The end of history, he writes, brings with it the conquest of ambiguity, and the end of moral and religious striving. The overcoming of ambiguity means that man is no longer torn apart in trying

${ }^{4}$ Cf. Pierre Teilhard de Chardin, The Phenomenon of Man Harper \& Row, New York (1965 edn.) and The Future of Man Harper \& Row, New York (1964); and Philip Hefner, "The Future as Our Future: A Teilhardian Perspective" in E. H. Cousins (ed.) op. cit, 15-39. The question about the parousia is explicitly raised by J. Stafford Wright, "The Theology of Teilhard de Chardin" in The Churchman 89 (1975) 37-8.

${ }^{5}$ P. Tillich, Systematic Theology vol. 3, Nisbet, London (1964) 421,

${ }^{6}$ Ibid. 422. 
to achieve two incompatible goals: individuality becomes compatible with true participation and divine centredness; free choice becomes compatible with entering in upon one's destiny. Tillich also portrays the end of moral and religious striving. "For love does what the law demands before it is demanded", and the heavenly Jerusalem is described as a city in which there is no temple, because God himself dwells there. $^{7}$

Tillich also declares that the end of history brings the destruction of all that is ultimately negative, and the fulfilment of the individual's uniqueness as a person. The first is expressed through the symbol of the last judgment; the second through the symbol of the resurrection of the body.

This "eternal conquest of the negative", however, may not be expressed in static terms. Here Tillich asserts that we must take seriously the perspective of process thought. "Eternal blessedness is not a state of immovable perfection ... The Divine Life is blessedness through fight and victory ... Time and change are present in the depth of Eternal Life, but they are contained within the eternal unity of the Divine Life." 8

Whilst he at least interprets the last judgment and the resurrection of the body as symbols, it may be seen that Tillich has almost no place for the parousia, even as a symbol. Perhaps the most that can be said is that the idea of parousia as presence, rather than as coming, is implied in his language about the presence of God in the heavenly Jerusalem. There is much in common, then, between the three approaches which we have so far examined. They contain insights into eschatology which can be fruitfully related to a doctrine of the parousia which has been arrived at on other grounds; but the parousia itself has no significant place within these eschatological perspectives. By contrast, we shall now examine four different approaches which have more specific connexions with a theology of the parousia.

The first of these approaches takes as its starting-point the radical importance of the expectation of an imminent parousia in the primitive Church. However, this expectation, it is argued, became obsolete and embarrassing for the New Testament and early Church when the parousia failed to arrive. This meant a radical re-casting and re-shaping of

${ }^{7}$ Ibid. 429 ; cf. 428.

${ }^{8}$ Ibid. $424-7$ and $430-47$. 
theology which may be described as the de-eschatologization of Christian doctrine.

Those who are already familiar with Albert Schweitzer's work on eschatology may perhaps assume at once that we are referring to his thought, and it remains true that he is the early inspiration behind this approach. However, more recently Schweitzer's position has been developed by two other writers, namely Fritz Buri and Martin Werner. ${ }^{9}$ Buri's work was published in 1934 and 1946-7; Martin Werner published his impressive study The Formation of Christian dogma in its first edition in 1941. A second edition appeared in 1954, and an English translation in 1957. The aspect of Schweitzer's interpretation which Werner took up and developed, is expressed by Schweitzer himself in the following words. He writes, "The whole history of 'Christianity" down to the present day ... is based on the delay of the Parousia, the non-occurrence of the Parousia, the abandonment of eschatology, the progress and completion of the 'de-eschatologizing' of religion which has been connected therewith". ${ }^{10}$

Following Johannes Weiss, Albert Schweitzer rightly believed that nineteenth-century liberal scholarship, with its bias towards immanentism, had grossly underestimated the importance of apocalyptic as a context of thought surrounding Jesus and Paul. Jesus, Schweitzer further argued, saw himself as standing at the very end of history. Like John the Baptist, he expected the coming of the kingdom of God in the immediate future. The arrival of the kingdom, which would take place at any moment, constituted a supernatural act of God which would entail the transformation of the elect and indeed of the world-order itself into a super-earthly state. Schweitzer continues, "The Parousia of the Son of Man, which is logically and temporally identical with the dawn of the kingdom, will take place before (the Twelve) shall have completed a hasty journey through the

9 F. Buri, "Das Problem der ausgebliedenen Parusie" in Schweizerische theologische Umschau (1946) 101ff.; Die Bedeutung der neutestamentlichen Eschatologie für die neuere protestantische Theologie Berne, Zürich (1934); and M. Werner, The Formation of Christian Dogma. An Historical Study of the Problem ETr. Black, London (1957).

10 A. Schweitzer, The Quest of the Historical Jesus. A Study of its

Progress from Reimarus to Wrede ETr. Black, London (1936) 358. 
cities of Israel to announce it". The words of Matthew 10.23 "mean this and nothing else"."11

Nevertheless, Schweitzer adds, "it is equally clear . . . that this prediction was not fulfilled ... An event of supernatural history which must take place ... failed to come ao about." 12 It is the merit of "the thoroughgoing eschatological school", Schweitzer argues, to see the key importance of this state of affairs. When the Kingdom, or the parousia, did not immediately appear, Jesus attempted to force its coming by fulfilling in his own person the Messianic woes which, in apocalyptic, belong to the events of the last days. In this, once again, Jesus was mistaken. Hence the whole presupposition of his ministry, work, and teaching, namely the belief in the imminence of the parousia, was false. Two alternatives, therefore, were left open to the church, apart from discarding the teaching of Jesus as irrelevant. Either they could try to perpetuate a belief in the imminence of the parousia, or else they could radically re-shape primitive Christian theology.

Paul, according to Schweitzer, attempted to preserve an eschatological perspective by re-interpreting the situation, and by combining prophetic and apocalyptic eschatologies, Fundamentally, he suggests, Paul "asserts that the first participators in the transient Messianic kingdom already have the resurrection mode of existence."13 Through union with Christ "the springtime of super-earthly life has already begun, even though else where in the world the winter of natural existence still holds sway". ${ }^{14}$ Thus "believers possess in advance the state of existence proper to the Messianic kingdom". ${ }^{15}$ Christians live, then, in a situation of eschatological tension, for there are, as it were, two timings of the eschatological clock. Believers assume in advance a resurrection mode of existence whilst the natural world-order continues. But this is an anomalous and strictly temporary situation which will be set in order at the parousia and general resurrection. The parousia remains absolutely necessary to Pauline eschatology.

How long, however, may the parousia be delayed before

11 Ibid, 357.

12 Ibid.

13 A. Schweitzer, The Mysticism of Paul the Apostle ETr. Black, London (1931) 90.

${ }^{14}$ Ibid, 110.

15 Ibid, 205. 
the eschatological perspective is lost, and Paul is interpreted in a different way? Martin Werner builds on Schweitzer's work to try to show that the whole history of Christian dogma constitutes a steady de-eschatologizing of primitive theology.

Realized eschatology, Werner insists, would have been impossible for Jesus. For when Jesus thought of the kingdom of God, he thought of all the great final events of apocalyptic including "the Messianic affliction, the glorious parousia of the 'Son of Man'... the general resurrection of the dead ... the overthrow of demonic powers, the transformation of all things."16 Thus, Werner declares, "The heart of the problem . . . lay in the fact that in consequence of the delay of the parousia a contradiction between the eschatological scheme and the actual course of history began to be apparrent". 17

The delay of the parousia led to an abandonment of primitive doctrine, since it no longer remained meaningful once it was deprived of its basic presupposition and context. In place of the idea of the gathered community of the last days, "the new watchword is: 'Christianity preserves the world" ". ${ }^{18}$ In Werner's words, "Heresy now became for centuries a general phenomenon", as men struggled to arrive at "a new interpretation of the Paul who had become a problem". ${ }^{19}$ Phrases, for example, such as "the crucifying of the world" or "the letter of the law" were understood in the Patristic Church in non-eschatological and therefore unPauline ways. ${ }^{20}$

The value of this approach of Schweitzer's and Werner's is that firstly it gives adequate weight (even if admittedly also too much weight) to apocalyptic as part of the context of the parousia-expectation. Secondly, it takes seriously the extent to which the presupposition of an imminent parousia coloured the whole theological perspective of the primitive Church. There is indeed a radical contrast between the early eschatological perspective which sits loose to the world, and which sees the kingdom as a supernatural act of God,

16 M. Werner, op. cit, 14.

17 Ibid, 22.

18 Ibid, 43.

19 Ibid, 55.

${ }^{20} \mathrm{Ibid}, 75$ and 85 . Werner argues, for example, that Epiphanius expresses a meaning diametrically opposed to Paul: the letter does give life! 
and the more "catholic" institutionalizing outlook of later years, which sees Christian faith as a "religion" which is at home in the world. We shall try to say more about this perspective of imminence towards the end of this paper. However, as it stands consistent eschatology cannot be accepted, especially in its particular account of the outlook of Jesus. Arthur Moore rightly comments, "On the thesis of Consistent Eschatology it remains a problem why the Christian sect did not go the way of other disappointed apocalyptic groups whose chosen Messiah had failed them, and in part return to orthodox Judaism, in part linger on as a sect until finally dying out". ${ }^{21}$

There are, of course, possible answers to this criticism, for example, that it was the genius of Paul that saved the day, or that Luke-Acts represents a radical re-casting of theology to answer this problem. However, the detailed arguments of Schweitzer and Werner can only be sustained if every part of the New Testament is radically re-interpreted from the point of view of a theological scheme which presupposes its own criteria of authenticity and dating. We cannot assume, for example, that it was only in later New Testament thought that the resurrection of Christ occupied no less central a place than the parousia. Indeed it would seem that in their zeal to do justice to primitive Christian eschatology Schweitzer and Werner have actually exaggerated the importance of the parousia and of belief in its imminence.

We must next consider the approach of Rudolf Bultmann. Bultmann regards the parousia as eschatological myth standing in need of existential interpretation. To understand how he arrives at this position, we must first glance briefly at his notion of myth, and then note how he takes three of Schweitzer's conclusions as fixed points in his eschatology.

Bultmann defines myth ' $\eta$ at least three distinct ways. Whether these are entirely consistent with one another has been doubted by several writers, including especially Ronald Hepburn and Roger Johnson. ${ }^{22}$ Mythology, Bultmann declares, "is the use of imagery to express the other worldly

21 A. L. Moore, The Parousia in the New Testament NovT Supp. 13, Brill, Leiden (1966) 47.

${ }^{22}$ R. A. Johnson, The Origins of Demythologizing. Philosophy and Historiography in the Theology of Rudolf Bultmann Brill, Leiden (1974) is an invaluable study. Cf. also R. W. Hepburn's essay in A. Flew and A. Macintyre (eds.) New Essays in Philosophical Theology S. C. M. London (1955) 227-42. 
in terms of this world, and the divine in terms of human life ... For instance, divine transcendence is expressed as spatial distance". ${ }^{23}$ Clearly in these terms language about the "coming" of Christ, especially his coming on the clouds, will be regarded as myth.

Bultmann, however, has two further ways of defining myth. According to the mythological world-view, he argues, "the world is viewed as a three-storied structure, with the earth in the centre, the heaven above, and the underworld underneath". ${ }^{24}$ Central to this world-view is the idea of the supernatural and the miraculous, and of divine interventions into human history. Similarly, from a temporal viewpoint, the New Testament "proclaims in the language of mythology that the last time has now come ... (Christ) will come again on the clouds of heaven to complete the work of redemption ... Sin suffering and death will be finally abolished. All this is to happen very soon ..." ${ }^{25}$ That which is mythological, on this definition, is that which portrays events in supernatural terms, especially as acts of God "from above". Finally, Bultmann also insists that myth objectifies the reality of which it speaks. Myth properly expresses man's beliefs about his own condition, but in so doing this "purpose is impeded and obscured by the terms in which it is expressed". ${ }^{26}$ For example, the myth of the last judgment looks as if it is a descriptive account of a supernatural event in the distant future. Its purpose, however, is supposedly to summon men to accept responsibility for their present actions.

These accounts of myth are brought to bear on eschatology, but it may also be said that in Bultmann's view New Testament eschatology confirms his view of myth, and the need for its existential interpretation. He takes up three points which were stressed, as we have seen, by Schweitzer.

Firstly, Jesus was supposedly mistaken in his expectation of the parousia. Thus Bultmann writes "The course of history has refuted mythology". ${ }^{27}$ "The mythical eschatology is unten-

${ }^{23}$ R. Bultmann, "New Testament and Mythology" in H. W. Bartsch (ed.) Kerygma and Myth I ETr. S.P.C.K. London $\left({ }^{2} 1964\right)$ 10, n. 2 (my italics).

${ }^{24}$ Ibid, 1.

${ }^{25}$ Ibid, 2.

${ }^{26}$ Ibid, 11.

${ }^{27}$ R. Bultmann, Jesus Christ and Mythology S.C.M. London (1960) 14. These lectures represent Bultmann's position in 1951. 
able for the simple reason that the parousia of Christ never took place as the New Testament expected. History did not come to an end, and as every schoolboy knows, it will continue to run its course. Even if we believe that the world as we know it will come to an end in time, we expect the end to take the form of a natural catastrophe, not of a mythical event such as the New Testament expects." 28

Secondly, Bultmann speaks approvingly of the insistence of Weiss and Schweitzer that the kingdom of God in the teaching of Jesus was eschatological and supernatural. Today, Bultmann declares, no New Testament scholar doubts this. ${ }^{29}$ But this makes the concept all the more clearly mythological, since it depends on the notion of a divine intervention in history. It reflects a conception of the world and of the nature of causality which is totally alien to the modern world with its scientific and historical notion of natural cause and effect. Bultmann argues, "To this extent the kerygma is incredible to modern man, for he is convinced that the mythical view of the world is obsolete... There is nothing specifically Christian in the mythical view of the world as such. It is simply the cosmology of a pre-scientific age". 30: Thus, "No one who is old enough to think for himself supposes that God lives in a local heaven ... We can no longer look for the return of the Son of Man on the clouds of heaven, or hope that the faithful will meet him in the air ( I Thess. 4.15ff.)". 31

Thirdly, Bultmann saw that in the form in which Schweitzer interpreted it, the New Testament view of the parousia had little practical relevance even at the level of man's selfunderstanding. But myth, he urged, should be interpreted rather than eliminated. What, then, could be said about the sense of imminence, underlined by Schweitzer? In the nineteen-twenties the work of the earlier Barth had suggested that the existential significance of the belief in an imminent parousia lay in the practical challenge of "recognizing the seriousness of one's own position now". ${ }^{32}$ Bultmann develops

${ }^{28}$ R. Bultmann, "New Testament and Mythology" loc. cit. 5.

${ }^{29}$ R. Bultmann, Jesus Christ and Mythology 13.

${ }^{30}$ R. Bultmann, "New Testament and Mythology" loc. cit. 3.

${ }^{31}$ Ibid, 4 (my italics).

32 A number of relevant passages from Barth's commentaries The Resurrection of the Dead and The Epistle to the Romans are collected together in G. Lundström, The Kingdom of God in the Teaching of Jesus Tr. Oliver \& Boyd, Edinburgh (1963) 141-4. 
this line of approach. The true significance of eschatology in the New Testament, he urges, is "that Christ is the ever present, or ever-becoming event ... the 'now' gets its eschatological character by the encounter with Christ or with the Word which proclaims him, because in this encounter with Him the world and its history comes to its end and the believer becomes free from the world in becoming a new creature". ${ }^{33}$

Bultmann argues that the demythologizing of the end of history is demanded by the New Testament itself because its message is not cosmological but anthropological or existential. Indeed Paul and John, he claims, already begin the process of demythologizing within its pages. Although Paul admittedly "does not abandon the apocalyptic picture of the future, of the parousia of Christ", nevertheless "the real bliss" for Paul comes in the present experience of the believer: "If any one is in Christ, he is a new creature" (2 Cor. 5.17). ${ }^{34}$ Bultmann writes, "The process of demythologizing began partially with Paul and radically with John. The decisive step was taken when Paul declared that the turning point from the old world to the new was not a matter of the future, but did take place in the coming of Jesus Christ ... After Paul, John de-mythologized the eschatology in a radical manner... 'Now is the judgment of this world ...' (Jn. 12.31). For John, the resurrection of Jesus, Pentecost, and the parousia of Jesus are one and the same event ..."35

Numerous criticisms can be brought against Bultmann's approach, and I have discussed many of these elsewhere. ${ }^{36}$ It should be noted, however, that Bultmann is not motivated solely by the concern to make the gospel message more acceptable to modern man, but by the belief that the New Testament itself demands its own demythologizing. He explicitly dissociates himself in this respect from earlier Liberalism, declaring, "The purpose of demythologizing is not to make religion more acceptable to modern man by trimming the

${ }^{33}$ R. Bultmann, "History and Eschatology in the New Testament" in NTS I (1954) 6 (my italics), 5-16.

${ }_{34}$ R. Bultmann, History and Eschatology Edinburgh Univ. Press (1957) 42; Cf. 38-73.

${ }_{35}$ R. Bultmann, Jesus Christ and Mythology 32-3.

36 A. C. Thiselton, "Myth, Mythology" in M. C. Tenney (ed.) The Zondervan Pictorial Encyclopedia of the Bible Zondervan, Grand Rapids (1975) vol. 4, 333-43; and also Language, Liturgy, and Meaning Grove Books, Nottingham (1975) 27-31. 
Biblical texts, but to make clearer to modern man what the Christian faith is". 37

Bultmann has rightly faced us with the problem of how far the New Testament writers themselves conceived of heaven and the parousia in a spatial or localized way. Do the New Testament writers themselves regard "coming on the clouds" as imagery? Paul Minear insists, for example, that we cannot accuse even the author of the Book of Revelation of holding "a naive three-storeyed idea of the physical world." 38 This raises a genuine difficulty. If we interpret what is really imagery or metaphor as literal description, or as ostensive referential language, we are in danger, as Bultmann warns us, of adding an artificial and unnecessary stumbling-block to the unbeliever's path, over and above the genuine and necessary stumbling-block of the cross. On the other hand, once we admit that part of the apocalyptic imagery is no more than imagery, at what point are we to draw the line?

The fundamental insights expressed by Bultmann are two. Firstly, he reminds us that we must beware of placing any stumbling-block in the way of modern man except the necessary one of the cross. Secondly, he reminds us that language about the parousia is not mere information given in order to satisfy curiosity about future events, but is to colour our present attitudes and conduct here and now. The existential significance of "waiting", for example, is important, and is well brought out by D. O. Via in his comments on the parable of the talents. Waiting is not to be a time when nothing happens and nobody comes. For the maidens in the parable the significance of "waiting" is that the length of time before the crisis is not under their control. Hence in this way the uncertainty and imminence of the expected event gives content and meaning to the present. ${ }^{39}$

However, this very point underlines the inadequacies of Bultmann's position. For the parousia in the New Testament remains a genuinely future event. It is not a mere linguistic cipher for calling attention to man's condition in the present. To say "Christ will come; live accordingly", is to say more

${ }^{37}$ R. Bultmann in H. W. Bartsch (ed.) Kerygma and Myth II S.P.C.K. London (1962) 182.

${ }^{38}$ P. S. Minear in W. Klassen and G. Snyder (eds.) Current Issues in New Testament Interpretation S.C.M. London (1962) 34.

${ }^{39} \mathrm{Cf}, \mathrm{D} . \mathrm{O}$. Via, The Parables. Their Literary and Existential Dimension Fortress Press, Philadelphia (1967) 126-8. 
than merely "Live as if Christ were to come". A related and parallel point is made with some force by Heinrich Ott in the context of a discussion of Bultmann's philosophy of history. Ott rightly asks, "Is this end of history, in which the meaning of all historical events will be disclosed .. a mere hypothesis for the sake of illustration? ... How can one say that an historical event has a meaning if the place where this meaning becomes known is non-existent?"40 The last judgment, Ott concludes, is demanded as a presupposition for the meaning of history even on the basis of Bultmann's own thought. Yet as an ontological reality it has no place within his theology.

We must also criticize Bultmann's attitude towards the whole conception of there being divine interventions in the course of history, of which the parousia is the climax. This notion is central to the theology of the New Testament, and can only be regarded as mythological on the basis of an unacceptable definition of myth. Wolfhart Pannenberg rightly comments, "The acceptance of divine intervention in the course of events ... is fundamental to every religious understanding of the world, including one which is not mythical in the sense in which comparative religion uses the term."41 Indeed Pannenberg asserts, "Neither belief in demons nor the 'three storey' world view of primitive Christianity is specifically mythical'; indeed "the eschatological conceptions of apocalyptic which are important in the New Testament cannot be understood as mythical without qualification". ${ }^{42}$

We conclude, then, that whilst Bultmann's approach raises very important and practical questions, it also encounters serious difficulties which make it unacceptable as it stands. We should heed his point that the doctrine of the parousia is to be interpreted in such a way that its relevance to the present is clearly seen, but it must also retain its status as a future event at the end of history when God in Christ will intervene decisively and publicly in the affairs of men.

So far we have reviewed three approaches to eschatology which left virtually no room for the parousia, and two which began by taking the parousia seriously, but which in the end

${ }^{40} \mathrm{H}$. Ott "Rudolf Bultmann's Philosophy of History" in C. Kegley (ed.) The Theology of Rudolf Bultmann S. C. M. London (1966) 58

${ }^{41}$ W. Pannenberg, Basic Questions in Theology vol. III ETr. S.C.M. London (1973) 14.

42 Ibid, 67. 
evaporated it of its genuinely future significance. We now turn to those approaches which see the traditional doctrine of the parousia as reflecting only the later strata of New Testament thought. We shall restrict our attention, however, to two particular writers in order to keep this paper within reasonable confines.

We first consider the argument of $J$. A. T. Robinson in his book Jesus and His Coming, which was published in 1957. Robinson draws heavily on the tradition of British scholarship represented by C. H. Dodd and T. F. Glasson. The essence of Robinson's argument is that "no evidence is to be found that the Parousia expectation formed part of the earliest strata of Apostolic Christianity". ${ }^{43}$ Indeed, more than this, Jesus himself did not expect that there should be a second "coming". Apocalyptic admittedly looked forward to a great intervention of God which would take the double form of vindication and visitation. ${ }^{44}$ But Jesus expected an immediate vindication following on his sufferings, and this was fulfilled in his resurrection and his going to God. ${ }^{45}$ The visitation of God, however, took place primarily in the entirety of his own ministry and in its wider consequences. ${ }^{46}$ But neither aspect points clearly to the expectation of a "second" coming, except in the later parts of the New Testament.

Although he builds on the work of Dodd and Glasson, it is Robinson's merit that in this particular book he attempts to base his conclusions on a painstaking exegesis of the text. We may glance first at his exegetical conclusions about passages which are said to reflect the earliest outlook of the primitive Church. The prayer "marana tha", "Come our Lord" (1 Cor. 16.22), Robinson claims, "has its setting in the primitive Eucharist". This "raises the question whether it means more than what is implied, say, in Rev. 3:20: 'Behold I stand at the door and knock ... I will come in to him and eat with him" ". ${ }^{47}$ He next considers the two standard references in the Acts speeches, namely 10.42 and 3.19-21. In Acts 10 he accepts that there is a reference to future judgment, but insists that "there is no suggestion that (Christ) will be judge

${ }_{43}$ J. A. T. Robinson, Jesus and his Coming. The Emergence of a Doctrine S.C.M. London (1957) 29.
${ }^{44}$ Ibid, 39-40.
45 Ibid, 40-58.
46 Ibid, 59-82.
${ }^{47}$ Ibid, 27. 
only at some second coming". ${ }^{48}$ His treatment of Acts 3 is complex and controversial. It cannot, he claims, refer to a second coming of Christ, for as he argues more fully elsewhere, "Jesus is here still only the Christ-elect, the messianic age has yet to be inaugurated." 49

How does Robinson dispose of the traditional interpretation of such passages in the Gospels as Mark 14.62: "You will see the Son of Man sitting at the right hand of Power, and coming with the clouds of heaven" (cf. Mt. 26.64; Lk. 22.69)? He sees these words as an echo, firstly, of Psalm 220.2, which speaks of divine vindication; and secondly, of Daniel 7.13, which speaks of "one like a Son of Man" coming with the clouds of heaven. The whole passage, Robinson insists, speaks "of a coming to God in ascent and vindication ... Jesus is not at this point speaking of a coming from God." 50 Moreover this "coming to God" is portrayed as an "imminent vindication ... o out of the very jaws of humiliation and defeat." The saying and its parallels are "a saying not of visitation from God, but of vindication to God". Jesus refers "to the moment of the Resurrection onwards". 51

On the other hand, with regard to the early Church in contrast to Jesus himself, "the early Church did expect a descent of Jesus on clouds from heaven". "The first mention of the Parousia hope is in I Thess. 1.10."52 Robinson has little difficulty in suggesting an hypothesis which would account for this development. Taking up the line of approach which has been made so familiar by C. H. Dodd's book The Parables of the Kingdom, he argues that to the second event of a future parousia "are transferred those warnings and promises in which Jesus sought originally to define the crisis that his presence involved". ${ }^{53}$ The crisis parables, for example, are given a new lease of life by re-applying them to a crisis which still lay in the future.

There are many difficulties to Robinson's view. Firstly, if the earliest community were accustomed to think of the

48 Ibid, 28.

49 J. A. T. Robinson, "The Most Primitive Christology of All?" in Twelve New Testament Studies S.C.M. London (1962) 144; rp. from JTS ns 7 (1956) 177-89.

${ }^{50} \mathrm{~J}$. A. T. Robinson, Jesus and his Coming, 45. (his italics).

${ }^{51}$ Ibid, 46, 50, and 51.

52 Ibid, 52 and 26.

53 Ibid, 93. 
parables of crisis as applying to confrontation by the word of Jesus, why was it not sufficient to re-apply these same parables to the effects of the evangelistic preaching of the early Church, in which Jesus, once again, confronted the hearer? Why did they require a re-application to a future parousia, unless of course this was part of their original purpose? Secondly, Robinson's exegesis is questionable at several points. For example, C. F. D. Moule calls in question his exegesis of Acts 3.19-21, concluding, "It is simpler, surely, to interpret the crucial words to mean that Jesus is already recognized as the previously predestined Christ ... who at the end is to be sent back again into the world". ${ }^{54}$ Robinson, it may be added, does not take the perfect tense in John in the same sense as he interprets it in Acts $3 .^{55}$ It may also go without saying that several scholars, including Norman Perrin and G. R. Beasley-Murray, have also questioned his exegesis of Mark 14.62. ${ }^{56}$ A third criticism may also be made. Whilst Robinson rejects Schweitzer's view that Jesus was mistaken about the parousia, it is now the New Testament Church who, in effect, makes the mistake. They fail to see that the eschaton has been realized in the coming of Christ. But this is precisely to fall prey to a lack of balance in eschatological perspective which, I have argued in another paper, gave rise to all Paul's problems at Corinth. ${ }^{57}$ As G. E. Ladd has pointed out, the perspective of "now" and "not yet" belongs to the wholeness of eschatology in every part of the New Testament. ${ }^{58}$

We have mentioned in passing that Robinson's thesis is similar at certain points to that of T. F. Glasson. It is worth noting that in 1963 Glasson published an expanded and revised edition of his earlier work, and that as recently as in 1971 he added a further defence of his conclusions in an article entitled " 'The Second Advent' - 25 Years Later". 59 In this article he re-asserts in particular his point that Judaism in the time of Jesus provides no evidence of a con-

54 C. F. D. Moule, "The Christology of Acts" in L. E. Keck and J. L. Martyn (eds.) Studies in Like-Acts S.P.C.K. London (1968) 168 (his italics).

${ }_{55}$ Cf. J. A. T. Robinson, Jesus and his Coming, 170.

${ }^{56}$ Cf. N. Perrin, The Kingdom of God in the Teaching of Jesus S.C.M. London (1963) 142-3; and G. R. Beasley-Murray's extended critical review in JTS ns. 10 (1959) 137 (cf. 134-40).

57 A. C. Thiselton, "Realized Eschatology at Corinth", forthcoming in NTS.

58 G. E. Ladd, "Eschatology and the Unity of New Testament Theology" in ExpT 68 (1956-7) 268-73.

s9 T. F. Glasson, in ExpT 82 (1971) 307-9. 
temporary belief that the Messiah would come down from the clouds. This doctrine, he argues, was read back into the gospel tradition by the early Church. But even if Glasson escapes part of the second criticism which we made against Robinson, the first, third, and part of the second still stand. Moreover the argument that Jesus did not borrow the doctrine from Judaism is self-defeating. For by the criterion of dissimilarity, this makes it all the more likely that we have here authentic material in the gospels.

We must also glance briefly at the work of Hans Conzelmann whose book Die Mitte der Zeit was published in 1954, and appeared in English under the title The Theology of St. Luke. Conzelmann writes, "The main motif in the recasting to which Luke subjects his source proves to be the delay of the parousia."60 In other words, Luke radically reinterpreted the traditions which reached him in such a way as to replace the expectation of an imminent parousia by the notion of a divinely-planned period of salvation-history stretching between the time of Jesus (the middle time) and the parousia. Stop-gap answers to the problem of the delay of the parousia were supposedly wearing thin, and Luke saw that it was no good simply to continue to assert that although the Lord delayed, he would nevertheless come soon. Hence he attempted to show that Jesus had foreseen a definite interval between the resurrection and the parousia. Far from being an embarrassment to the Church, this period constituted a necessary and positive stage in the outworking of God's plan. This is in harmony with his task as a historian in the writing of Acts. As Käsemann puts it, "One does not write the history of the Church if one daily expects the end of the world". 61

Conzelmann argues his case by means of the methods of redaction-criticism, comparing numerous passages in Luke with their parallels (or often omissions) in Matthew and Mark. He examines various passages in Luke, which seem explicitly to reject the notion of an imminent parousia. These include for example Luke 19.11: "Jesus proceeded to tell a parable because he was near to Jerusalem and because they supposed that the kingdom of God was to appear immedi-

${ }^{60} \mathrm{H}$. Conzelmann, The Theology of St. Luke Faber, London (1960) 131. 28.

61 E. Käsemann, Essays on New Testament Themes ETr. S.C.M. London (1964) 
ately". Conzelmann comments, "The disciples interpret the approach to the city as the approach to the parousia instead of to the passion. They have a wrong conception of . . . eschatology. It is not yet - not for a long time . . " "62 Acts 1.6-8 is also included: "It is not for you to know the times ..." Conzelmann remarks that here the time of the parousia "is dismissed on grounds of principle". ${ }^{63}$ Luke 21.5-36 contains the important assertion "the end is not yet" (verse 9). As against Luke's historical perspective, Conzelmann argues, Mark and Matthew set the saying about the destruction of Jerusalem in the context of the parousia. For Luke, the series of signs "do not imply that the coming is imminent, but they point to a long period which comes first". ${ }^{64}$ On the well-known saying that "the Son of Man shall be seated at the right hand of the power of God" (Lk. 22.69; cf. Mk. 14.62), Conzelmann concludes that whereas the Markan parallel refers to the parousia, Luke refers to an exaltation of Christ "which is described as beginning now". 65

The value of Conzelmann's work is to show that the period of waiting before the parousia is fully recognized in Luke, and to underline the point, associated especially with Oscar Cullmann, that salvation-history as a concept is not alien to the New Testament. Indeed the view which Conzelmann ascribes only to Luke is interpreted as a wider and more dominant New Testament perspective by Cullmann. ${ }^{66}$ However, there are at least two serious objections to Conzelmann's account of eschatology. Firstly he tends to overemphasize the distinctiveness of Luke's approach by exaggerating the note of imminence and immediacy in Matthew and Mark. Is it true that Matthew and Mark contain no hint at all of any interval between the resurrection and the parousia? This is achieved partly by following the kind of circular argument found in the work of Erich Grässer, whereby Grässer denies to Jesus any saying which presupposes such an interval. ${ }^{67}$ The heart of

${ }^{62} \mathrm{H}$. Conzelmann, op. cit, 74.

${ }^{63}$ Ibid, 121.

64 Ibid, 130.

65 Ibid, 116.

66 O. Cullmann, Salvation in History ETr. S.C.M. London (1967); and "The Return of Christ" in The Early Church S.C.M. London (1956).

${ }^{67}$ Cf. E. Grässer, Das Problem der Parusieverzögerung in den Synoptischen Evangelien und in der Apostelgeschichte $Z N W$ Beihefte 22, Töpelmann, Berlin ( $\left.{ }^{2} 1960\right)$. 
the problem is very well expressed by J. Kodell. He writes, "Conzelmann may have oversimplified the position of Mark regarding the parousia, making him the straw man to Luke's innovative genius. Mark, too, incorporates the idea of a delayed parousia $(13.10,32) . " 68$

The other serious criticism is that there remains a theme of imminence in Luke, which is too prominent for Conzelmann to dismiss merely as careless editing, especially when he has portrayed him as one who is constantly concerned for every detail of redaction. For example, the parable in Luke 12.38-48 is told in order to challenge the servant who says "the Lord delays" (verse 45). Other examples are suggested in a penetrating study by S. G. Wilson. ${ }^{69}$ Indeed H. -W. Bartsch goes further than Wilson. Whereas Wilson sees both the "delay" strand and the "imminence" strand to be present in Luke, Bartsch sees the need for vigilance as a major Lukan preoccupation, believing that he is specifically concerned to disentangle a mistaken confusion between the parousia and the resurrection. The Rich Fool (only in Luke) is told "this night your soul is required for you" (12.10), and Jesus tells his disciples, "If the householder had known at what hour the thief was coming, he would have been awake ... "You must also be ready" $(12.39,40)$. "As it was in the days of Noah, so will it be in the days of the Son of Man. They ate, they drank, ... until the day when ... the flood came and destroyed them all"' $(17.26,27)$. Bartsch explicitly entitles his study Wachet aber zu jeder Zeit.

We must now draw our survey to a conclusion by looking finally at the movement known as the theology of hope, and in particular at Jürgen Moltmann and Wolfhart Pannenberg. Moltmann's book Theology of Hope appeared in German in 1965, and in English two years later. His series of essays published under the title Hope and Planning (German 1968, English 1971) represents what he describes as both preparatory work for, and the sequel to, Theology of Hope. Even his most recent book The Crucified God relates in some measure to the theme of hope, for he describes the cross as "none other than the reverse side of the Christian theology of hope". He explains "Unless it apprehends the pain of the negative, Christian

${ }^{68} \mathrm{~J}$. Kodell, "The Theology of Luke in Recent Study" in Biblical Theology Bulletin 1 (1971) 142.

${ }^{69}$ S. G. Wilson, "Luke's Eschatology" in NTS 15 (1968-9) 330-47. 
hope cannot be realistic and liberating". ${ }^{70}$ Pannenberg's great studies include Jesus, God and Man (English, 1968) and the three volumes of essays entitled Basic Questions in Theology (English 1970-73). Other "theologians of hope" whom we cannot consider here include Rubem Alves, Johannes Metz, and Carl Braaten.

Moltmann begins by asserting that "from first to last, and not merely in epilogue, Christianity is eschatology, is hope, forward looking and forward moving, and therefore also revolutionizing and transforming the present". ${ }^{71}$ God is the God of hope (Rom. 15.13). Paul, Moltmann reminds us, declares, "We are saved by hope. But hope that is seen is not hope; for what a man sees, why does he yet hope for?" (Rom 8.24). Hence Moltmann exclaims, "There is therefore only one real problem in Christian theology ... the problem of the future"; and writes "In the Christian life faith has the priority, but hope the primacy."72 Unlike Schweitzer, Moltmann and Pannenberg do not view Christian eschatology as an embarrassment resting on a mistake. Unlike Bultmann, they do not regard it as peculiarly belonging to first-century myth. Unlike Robinson, they do not see its centre of gravity as lying in the past or the present, rather than the future.

Indeed with regard to this last point, Moltmann has strong words to say about what he calls the sins of presumption or despair. He declares, "Presumption is a premature self-willed anticipation of the fulfilment of what we hope for from God. Despair is the premature arbitrary anticipation of the non-fulfilment of what we hope for from God, Both forms of hopelessness, by anticipating the fulfilment or by giving up hope, cancel the wayfaring character of hope."73 Presumption wrongly anticipates God's "yes"; despair wrongly anticipates an answer "no". But Christian faith must not be presumptuous. It should not embrace the mood of one who has already arrived at his final destination. It should be marked by the mood of pilgrimage, travel, exodus, openness, expectation, change, readiness, even unrest.

In this connexion Moltmann believes that the perspective of the Old Testament has not become entirely irrelevant.

70 J. Moltmann, The Crucified God ETr. S.C.M. London (1974) 5.

71 J. Moltmann, Theology of Hope ETr. S.C.M. London (1967) 16.

${ }^{72}$ Ibid, 16 and 20.

${ }^{73}$ Ibid. 23 (my italics). 
This perspective, we may note, has been admirably captured not only by Moltmann but by Kornelius Miskotte in his haunting book When the Gods are Silent. The Old Testament asserts the silence of the gods, and the hiddenness of God. For God, in the Biblical perspective, is not only the God who "is there" but also the God who "comes". He is not simply a static presence, which Moltmann describes as "epiphany". He comes to us, deals with us, encounters us, meets us, in ways which sharpen our appetite for the great "coming" of the future. The Christian never outgrows what Moltmann calls "the horizon of expectation". ${ }^{74} \mathrm{He}$ reminds us, rightly, that this is the perspective of the Epistle to the Hebrews: "Let us go forth to him outside the camp, bearing his reproach. For here we have no continuing city, but seek one to come" (Heb. 13.13, 14). ${ }^{75}$

One of Pannenberg's most important contributions is to show, in greater detail than Moltmann, how this forwardlooking perspective relates to questions about truth and about revelation. In his essay on the nature of truth Pannenberg points out that truth in the Bible is not simply the truth of logical necessity or analy tical definition (It is "true" that the sum of the angles of a triangle is $180^{\circ}$, independently of empirical investigation). The truth of God is that which is proved anew in our experience day by day. (It is therefore contingent truth which depends on the occurrence of particular events.) But this raises the problem that future events may call in question judgments which we have made on the basis of events or experience up to the present. Thus in his essay on "Eschatology and the Experience of Meaning". Pannenberg explains, "What formerly seemed insignificant may perhaps appear later as of fundamental importance; and the reverse may be true". Thus, with respect to the individual, "The final significance of the events of our life ... can be measured only at the end of our lives, in the hour of our death". ${ }^{76:}$ But this principle must be extended beyond the horizons of the individual. The meaning of history as a whole, and the truth of what historical events disclose, can be assessed only at the end of history, when history is complete.

74 Ibid. 334.

75 Ibid. 304.

76 W. Pannenberg, Basic Questions in Theology vol. 3, ET. S.C.M. London (1973) $201 ; c f .192-210$. 
This approach is not to be dismissed merely on the grounds thatsit reflects the influence of Hegel. Pannenberg owes much to Hegel, and insists, "Hardly any of the great thinkers of the modern age have done as much as Hegel to set the Christian religion back upon the throne from which the Enlightenment had removed it."77 Pannenberg stands in the philosophical tradition that goes back to Hegel through Bloch, Marx and Feuerbach, in contrast to the Bultmannian individualism which goes back through Heidegger to Kierkegaard. Moltmann, similarly, explicitly repudiates the individualistic perspective of Bultmann's hermeneutic in his significant essay "The Revelation of God and the Question of Truth". The difficulty of Bultmann's approach, Moltmann argues, is that "the whole of reality in terms of its most comprehensive horizon is no longer understood as cosmos or history, but rather in terms of man, who, as subject, makes himself into its mid-point". ${ }^{78}$ Moltmann insists, however, that we cannot arrive at truth from a purely man-centred perspective, but only in the light of history as a whole, which embraces the future. "It is only from its End that the total reality of the world will be complete". ${ }^{79}$

Nevertheless, how can we know this future until it becomes present and therefore no longer future? Pannenberg declares that "the answer lies in the proleptic character of the Christ event." 80 The resurrection of Christ points forward in an anticipatory way to "the eschatological event which binds history into a whole". ${ }^{81}$ Thus it would not be true to say that Pannenberg stresses the parousia at the expense of the resurrection. Christ gives a proleptic and provisional view of the end. This is part of what is meant by a doctrine of revelation: the future is provisionally disclosed in advance. The apocalyptic setting of the resurrection hope makes this more meaningful. For it shows that, on the one hand, the resurrection is one of the last events of the end time; and on the other hand, that

${ }^{77}$ Ibid. 159.

78 J. Moltmann, Hope and Planning ET, S.C.M. London (1971) 8.

79 W. Pannenberg, "The Revelation of God in Jesus of Nazareth" in J. M. Robinson and J. B. Cobb (eds.) New Frontiers in Theology: III, Theology as History, Harper \& Row, New York (1967) 132.

80 W. Pannenberg, Basic Questions in Theology vol. 2, ET, S.C.M. London (1971) 24. 122.

${ }^{81}$ W. Pannenberg, "The Revelation of God in Jesus of Nazareth" loc. cit. 
the God of promise is the God of world-history, which embraces all reality. Apocalyptic sees the future not only in terms of a salvation-history wrought by the God of a particular people, Israel; but in terms of world-history wrought by the God who is Lord of all. Hence it concerns not only the truth of a particular "religion", but all truth. For, once again, "Each individual entity has its meaning only in relation to the whole to which it belongs". ${ }^{82}$

It need hardly be said that the perspective unfolded by Moltmann and by Pannenberg is constructive, even visionary. It sets the Christian hope in a positive context, and underlines its theological necessity and value. If we have reservations, these are two. Firstly, like the theologies of process thought and Teilhard de Chardin, Moltmann tends to speak in general terms of the end rather than in more specific terms of the parousia of Christ. His elucidation of the future in terms of social and political progress, for example, appears to fill virtually the entire content of what he envisages as the future. ${ }^{83}$ Secondly, in spite of Pannenberg's emphasis on revelation, the impression is given that even Christian revelation may yet be called in question by the future. He writes that truth can never be seen as "already existing somewhere as a finished product". ${ }^{84}$ In the sense that the interpretation of revelation is an ongoing process, this is correct. But we must also leave room for the perspective expressed in Hebrews that whereas revelation in the days of the prophets was "partial and piecemeal ... in these last days God has spoken to us by his Son ..." $(1.1,2)$.

It is time to conclude by attempting to show how a positive approach can be made to the doctrine of the parousia, which takes account of the variety of positive insights which we have noted in the seven types of approach which we have reviewed.

First and foremost, the doctrine of the parousia should be viewed within its proper theological context. In the context of everyday life, the warning, or encouragement, that Christ may return at any moment often seems to take on the appearance of an unconvincing bluff. Christian average-

82 W. Pannenberg, "Response to the Discussion" ibid. 242.

${ }^{83}$ Cf. J. Moltmann's essay in E. H. Cousins (ed.) op. cit. 55-9; 89-104; and Theology of Hope 304-38; and Hope and Planning 155-77.

${ }^{84}$ W. Pannenberg, Basic Questions in Theology vol. 2, 21. 
adjusters in the world of insurance do not give different odds on life assurance policies from other people; and congregations soon tire of the "Wolf! Wolf!" mentality of certain eschatological preachers. But if so, what are we to make of such notions as that of imminence or waiting?

Moltmann has rightly reminded us that these categories can be meaningful only against the background of faith in the God of promise. Eschatology was not born out of disillusion and despair, but out of the conviction that the God who is faithful will perform his word, and that his promise will be more than abundantly fulfilled. Christian hope occurs wherever there is a gap between a state of affairs as it is, and God's declared will for his people. Realized eschatology and spiritual "enthusiasm" attempts to bridge this gap by constructing a phantasy world in which man live as if all were fulfilled. The eschatological realist waits for God's time. He recognizes that he is not in control of time, but waits on God in yieldedness, in a spirit both of acceptance and yet of expectancy, for God to "come" and for him to "act" in his good time. It is an expression of man's worship in the face of the sovereignty of God.

This carries with it a modest acceptance of the fact that the present is not simply a time of unqualified victory, but a period which is marked by ambiguity as well as truth, by ignorance as well as knowledge, and by striving as well as rest. New Testament scholars have often attempted to describe this as an experience of eschatological tension in which the believers experiences both the "now" and the "not yet". ${ }^{85}$ There is a sense in which, as Miskotte argues, God remains hidden in the present, even if because of this very fact he also "comes" in the situations of everyday life.

This is not, however, the whole picture. For history is moving towards the goal of the great and final "coming", when that which is ambiguous and fragmentary will be done away. The exodus will end in the arrival in the promised land; the exile will end in the return; the pilgrimage will end in homecoming.

As Robinson pointed out, there are two elements to the fulfilment of man's hopes in Christ, namely visitation

${ }^{85}$ See especially N. Q. Hamilton, The Holy Spirit and Eschatology in Paul Oliver \& Boyd, Edinburgh (1957) passim. 
and vindication; and we have seen glimpses of both aspects already in the resurrection of Christ and the gift of the Spirit. The Spirit's work is not only to bring Christ's presence to the believer, but also to judge him and to vindicate Christ in his eyes. But the believer longs for the time when this will happen not only in his own life, but publicly and unambiguously in the eyes of all men. Hence the Church rightly looks forward to a moment of public visitation and public vindication, which passages such as Matthew 24.29ff. describe in cosmic terms.

Bultmann rightly points out that any spatial notion of travelling through the stars will hardly be the main point (if it is a point at all) about the parousia. But he is wrong to empty this event of all cognitive or objective content whatever. This is the moment when "the hidden shall be revealed" (Mt. 10.26); "the lowly shall be exalted" (Mt. 18.4); "the last shall be first" (Mt. 19.30). The measure of truth will be the final and unambiguous verdict of God, which will be the "what is" of history-as-awhole. In this sense, Tillich is right when he says that judgment involves the destruction of the negative. For when the whole of reality will have been unmasked and set before the eyes of men, there will be no room for disguises, deceits, or "misunderstandings", and no room for second thoughts. For the moment of the "coming" or "presence" (parousia) os also the moment of the great unveiling (apocalypsis).

Most of the writers to whom we have referred have rightly stressed that Christian eschatology is set in cosmic terms, not in terms of the individual's moment of death. It is a symptom of our modern individualism that we hear protests to the effect that the threat of imminent individual death is more real to the average Christian than the expectation of the parousia of Christ. To make this protest at all is to confess to a certain degree of self-centredness. The great questions which concerned Jesus and Paul were not questions about their own personal destiny, so much as questions about the destiny of the Church and the world, and especially the cosmic purposes of God. How and when will God vindicate his name? How and when will God be true to his promises? (cf. Rom. 11.33-36).

Meanwhile, "expectation", as the philosopher Ludwig Wittgenstein has shown, is not so much a state of mind as an 
attitude which is expressed in certain conduct. ${ }^{86}$ Expecting a friend to come to tea at four o'clock entails not so much a particular mental state, as doing appropriate things like writing the date in my diary, laying the table at half past three, wondering whether he smokes and putting out an ashtray, and so on. If I "expect" something good to happen soon, I may not have an image of its occurrence lying in my mind for a number of days; but I may be found humming a tune, or whistling, even though "while I whistled I wasn't thinking of him". ${ }^{87}$ In the same way, belief in the imminence of the parousia is not primarily a conscious mental state which has to be sustained with effort. It is a practical attitude. Paul expresses it in 1 Corinthians 7 in terms of sitting light to the things of the world, and looking beyond them to the future goal. It is waiting on God and living life in a way which acknowledges his sovereignty as Lord over time, and which trusts him as the faithful One who will perform his promises. Such an attitude is neither peculiar to the first century nor obsolete now. It looks to the moment, as Pannenberg and Moltmann have reminded us, when God in Christ will be revealed not only as Lord of the individual believer, or even of Israel and the Church, but as Lord of all peoples and all history, vindicated and adored.

${ }^{86}$ L. Wittgenstein, Philosophical Investigations, Blackwell, Oxford, $\left({ }^{3} 1967\right)$ sections 572-82; Philosophische Bemerkungen, Blackwell, Oxford (1964) sections 21-31; and Zettel Blackwell, Oxford (1967) sections 58-68 and 71-2.

${ }^{87}$ L. Wittgenstein, Zettel sections 63-4. 